\title{
The Effect of The College Reputation on Student's Decision Making to Choose It
}

\author{
Nuriah Vani Ramdhiani, Rahma Wahdiniwaty \\ Master of Management Study Program \\ Universitas Komputer Indonesia \\ Bandung, Indonesia \\ rahmawahdiniwaty.@unikom.ac.id
}

\begin{abstract}
The research was aimed to investigate the influence of the reputation of a college toward the student's decision in determining it as their place of study. The research method used in this study is descriptive and verification analysis. The study case was conducted in a private university in Bandung, The questionnaires were distributed on 100 respondents. The quantitative method, validity, reliability and simple linear regression was conducted in the research. The finding of the research showed that the reputation of college influences a decision to choose a college. The factors of good reputation owned by a college reflect the quality of the college. This research has advantages in giving recommendation to the college to maintain their reputation or to improve their reputation considering the strong relation between reputations with student's decision making to choose it as their study place.
\end{abstract}

Keywords - reputation, college, decision to choose

\section{INTRODUCTION}

The decision making process to choose a college as the place of study certainly was determined by several factors. One of the crucial factor is the reputation of a college. Reputation representing the success in the past, present and in the future. Indeed reputation considering as mindset or psychological image of the institution [1] According to reference 2, every university must be able to create competitive advantage, in which university reputation as one element in it. The good reputation can attract the student's candidate to choose the university. Additionally, the good university reputation create good image to their graduates so the good company interest to recruit them [2].

There were many previous research indicated that the reputation of a company has a strong relation to the positive image. Unfortunately, the research was performed in commercial firms not in the college $[3,4,5]$. In the education sector, the research found that the reputation of the college has significant influence toward the attitude of the prospective student. However, the research did not explain the exact percentage of the college influence [6]. A prior study claimed that the interest to the major has become a crucial factor in determining student's decision-making. Unfortunately, there was not find the explanation about reputation factor in it [7].
Based on those prior researches, this study was purposed to analyze the influence of the reputation of a college toward the student's decision to determine it as their place of study

The study case was conducted in a private university in Bandung, The questionnaires were distributed on 100 respondents. The quantitative method, validity, reliability and simple linear regression was conducted in the research.

\section{METHOD}

The research was conducted at a private university in Bandung, Universitas Komputer Indonesia. The study case was performed by distributing a series of questionnaires to the students of informatics engineering department. The respondents amounted 100 person and the questionnaires were distributed in July 10, 2018. The Likert scale was used to give score to the questionnaire [8]. Quantitative method was performed to analyze the data, validity test was calculated by Pearson formula. Reliability test performed on the data as well.

This study has two variables, namely the dependent variable, in this case the decision to choose $(\mathrm{Y})$, and the independent variable that is reputation $(\mathrm{X})$. This is illustrated at Thinking Framework in Figure 1.

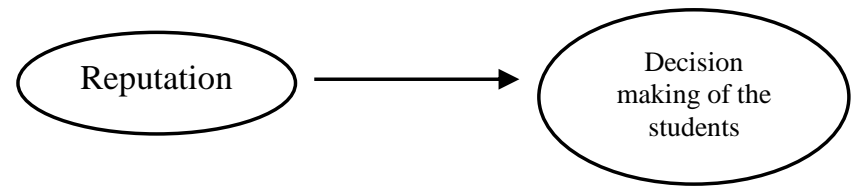

Fig. 1. Thinking Framework

In accordance to the results from the calculation using Slovin formula, the research sample was rounded to 100 students. Each statement was tested for its validity and reliability level. The validity test was performed using Pearson's correlation analysis [8]

$F=\frac{n\left(\sum x y\right)-\left(\sum x\right)\left(\sum y\right)}{\sqrt{\left[n \sum x^{2}-(x)^{2}\right]\left[n \sum y^{2}-\left(\sum y\right)^{2}\right]}}$

Remarks : 
$\mathrm{rxy}=$ The correlation coefficient is sought

$\mathrm{x} \quad=$ Total item score

$\mathrm{y}=$ Amount of total score (all of item)

$\mathrm{n} \quad=$ Number respondent

Furthermore, reliability testing (questionnaire's reliability level) was performed using Cronbach Alpha formula [9].

$$
r_{i}=\left(\frac{k}{k-1}\right)\left(1-\frac{\sum \sigma_{b}^{2}}{\sigma_{t}^{2}}\right)
$$

Remarks:

$$
\begin{array}{ll}
\mathrm{ri} & =\text { Instrument reliability } \\
\mathrm{k} & =\text { Total Question } \\
\sum \sigma \mathrm{b} 2 & =\text { Number of varied items } \\
\sigma \mathrm{t} 2 & =\text { Total Varian }
\end{array}
$$

The criteria for decision making in reliability testing was achieved if the instrument reached the reliability coefficient of > 0, 6 (See Table 2).

Figure 2 showed that the research used the variable credibility, reliability and image as the variable of reputation. [10]

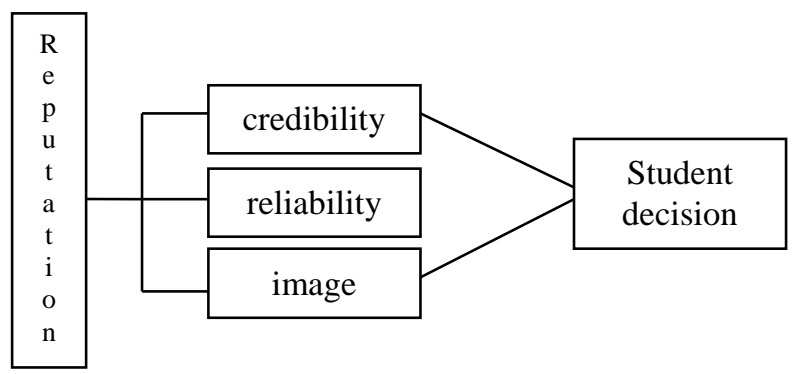

Fig. 2. The variable of Reputation

\section{RESULTS}

From the results of the validity test, it is known that all the points of the reputation variable $(\mathrm{X})$ and the decision to choose (Y) are declared valid. This is seen from the results of the correlation between the results of the respondents' answers in each question / indicator point with a total value obtained by significant results [9].

In terms of reliability test results obtained the results that the Cronbach's Alpha value of both variables is above 0.60. Thus it can be concluded that the reputation $(\mathrm{X})$ and purchasing decision $(\mathrm{Y})$ variables are declared reliable. This means that if the data is used on different objects and research times, it will still give the same results as those produced in this study.

The hypothesis states that reputation has a positive effect on the decision to choose. T-test results are significant and positive, which means reputation $(\mathrm{X})$ has a positive and significant effect on the decision to choose $(\mathrm{Y})$ in Unikom.

Figure 3 shows what percentage of influence on each variable of reputation on student decisions. From the figure,

\begin{tabular}{|c|c|c|c|}
\hline \multirow{4}{*}{ Reputation } & The Variable & $\begin{array}{l}\text { The Influence } \\
\text { toward level }\end{array}$ & \multirow{4}{*}{$\begin{array}{c}\text { Student } \\
\text { Choice }\end{array}$} \\
\hline & Credibility & $80 \%$ & \\
\hline & Reliability & $60 \%$ & \\
\hline & Good image & $70 \%$ & \\
\hline
\end{tabular}
it can be seen that the credibility variable has the greatest influence. A credibility was built to convince potential customers to instill trust in their minds Table I.
TABLE I. THE INFLuence TOWARD LEVEL OF THE VARIABLE

Any signal will be evaluated by the receiver by, among other factors, the credibility of the source. The higher the credibility, the more persuasive the source. Credibility must be before the message or action to have any significant effect [11].

Once a reputation is built and being established, the firm has to maintain that reputation with as much as possible. A firm that fails to follow through loses its credibility; to rebuild credibility, it must repaid the high costs of reputation building.

The point is, credibility is a trust of the current will and a historical idea based on behaviors in the past. Credibility is dynamic and also reputation, they are usually always changing. To build reputation and credibility are processes.

Corporate image and reputation are two important things to developing and maintaining a loyalty relationship of consumer [12]. In educational sector, these thought is used extensively as positioning instruments in influencing student's choice of his higher education college [13]. The meaning of the role between corporate image and reputation will lead the management in using both of them more effectively in strategy of communication that aim in enhancing corporate positioning.

Corporate image is illustrated as the impression in overall that created in the public's mind about it corporate [14]. Corporate image is the result of an aggregate process so that consumer can compare and show the real differences between various attributes of corporate.

Learn whether the effect of changes in the provision of information about the intention of a potential consumer in buying a product or service is often overlooked.

The phenomenon that occurs in UNIKOM is the high reputation that was successfully built by Unikom, has increased the number of students each year tend to be stable. But in the 2017-2018 academic year there was a decrease in the number of students accepted. This is where research is done, how it can happen.

Judging from the results of data analysis that has been carried out on all data obtained, it can be concluded that there is a positive and significant influence on reputation (X) variables on the decision to choose $(\mathrm{Y})$. In addition, if the reputation variable rises, then the decision decision variable also increases, and vice versa if the reputation variable falls, there will be a decrease in the decision variable to choose.

Before deciding to choose a product / service, consumers are often faced with several choices from similar products before deciding to choose. For this reason, the strength of a reputation is needed to influence the decision to choose from a consumer. In reputation variables, the indicators used are credibility, company reliability, and good name [10].

From the figure 2, it was indicated that the credibility has significant influence on student decision to choose a college. It was in line with the prior research of Goldsmith and Newell (2000) that used Path analysis to confirmed that endorser credibility had its strongest impact on advertisement while corporate credibility had its strongest impact on 
consumer reaction. The findings suggest that corporate credibility plays an important role in consumers' reactions to advertisements and brands, independent of the equally important role of endorser credibility [15].

The credibility of an organization is determined by the consistency between action and the message in the advertising or logo. Linking reputation with the credibility, reputation is a result of a series of credible action. Reputation usually build in a long period. If the organization repeatedly succeeds to fulfill the commitment ad its promises, it will creates the good reputation of the organization [16].

According to reference [17], the emotional component of institutional image and institutional reputation may share a close relationship because of the psychological dimensions. The psychological image contribute to the satisfaction of costumers. These dimensions are manifested by the consumer's attitudes and beliefs which rely on past actions of the organization or previous experiences. The organization. image and reputation can both be used as effective means of predicting the future outcome of the service production process and, perhaps, considered as the most reliable cues to signal the ability of a service organization to satisfy the customer's desires.

Types of Data and Sources Data in this study are primary data and secondary data. Data collection method in this study uses observation, questionnaires, interviews and literature studies.

\section{CONCLUSION}

The finding of the research showed that the reputation of college influences a decision to choose a college. The research contributed to provide literature concerning the reputation of the college. Considering the strong relation between reputation and the students decision to choose a college as their place of study, it was hoped that through finding of the research, the college will maintain its reputation through the three variable such as credibility, reliability and image. Further research on other variable on reputation need to be conducted in the future.

\section{ACKNOWLEDGMENT}

The authors want to give a gratitude to all those who helped in this research and UNIKOM, hope the results of the research can provide great benefits for those who need it.

\section{REFERENCES}

[1] Brewer, Ann, and Jingsong Zhao. "The impact of a pathway college on reputation and brand awareness for its affiliated university in Sydney." International Journal of Educational Management 24.1 (2010): 34-47.

[2] Finch, David, Sarah McDonald, and Julie Staple. "Reputational interdependence: An examination of category reputation in higher education." Journal of Marketing for Higher Education 23.1 (2013): 34-61.

[3] Cravens, Karen, Elizabeth Goad Oliver, and Sridhar Ramamoorti. "The reputation index:: Measuring and managing corporate reputation." European Management Journal 21.2 (2003): 201-212.

[4] Cretu, Anca E., and Roderick J. Brodie. "The influence of brand image and company reputation where manufacturers market to small firms: A customer value perspective." Industrial marketing management 36.2 (2007): 230-240.

[5] Yoon, Eunsang, Hugh J. Guffey, and Valerie Kijewski. "The effects of information and company reputation on intentions to buy a business service." Journal of Business research 27.3 (1993): 215-228.
[6] Merchant, Altaf, et al. "Effect of university heritage and reputation on attitudes of prospective students." International Journal of Nonprofit and Voluntary Sector Marketing 20.1 (2015): 25-37.

[7] Malgwi, Charles A., Martha A. Howe, and Priscilla A. Burnaby. "Influences on students' choice of college major." Journal of Education for Business 80.5 (2005): 275-282.

[8]Gliem, Joseph A., and Rosemary R. Gliem. "Calculating, interpreting, and reporting Cronbach's alpha reliability coefficient for Likert-type scales." Midwest Research-to-Practice Conference in Adult, Continuing, and Community Education, 2003.

[9] R Kothari and G Garg, 2014. Research Methodology Methods and Techniques 3rd New Age International (P) Limited, Publishers. New Delhi.

[10] Miles, Morgan P., and Jeffrey G. Covin. "Exploring the practice of corporate venturing: Some common forms and their organizational implications." Entrepreneurship theory and practice 26.3 (2002): 2140.

[11] Sobel, Joel. "A theory of credibility." The Review of Economic Studies 52.4 (1985): 557-573.

[12] Dick, Alan S., and Kunal Basu. "Customer loyalty: toward an integrated conceptual framework." Journal of the academy of marketing science 22.2 (1994): 99-113.

[13] Nguyen, Nha, and Gaston LeBlanc. "Image and reputation of higher education institutions in students' retention decisions." International Journal of Educational Management 15.6 (2001): 303-311.

[14] Barich, Howard, and Philip Kotler. "A framework for marketing image management." MIT Sloan Management Review 32.2 (1991): 94.

[15] Bowman, Nicholas A., and Michael N. Bastedo. "Getting on the front page: Organizational reputation, status signals, and the impact of US News and World Report on student decisions." Research in Higher Education 50.5 (2009): 415-436.

[16] Herbig, Paul, and John Milewicz. "The relationship of reputation and credibility to brand success." Journal of consumer marketing 10.3 (1993): 18-24.

[17] Nguyen, Nha, and Gaston LeBlanc. "Image and reputation of higher education institutions in students' retention decisions." International Journal of Educational Management 15.6 (2001): 303-311. 